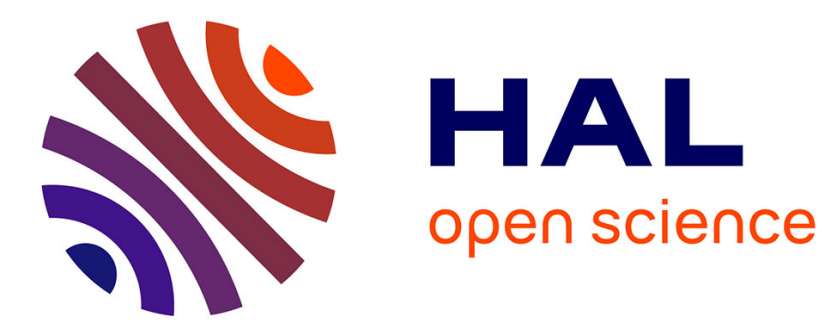

\title{
Reply: Janus kinase $1 / 2$ inhibition with baricitinib in the treatment of juvenile dermatomyositis
}

Yves Allenbach, Lois Bolko, Olivier Benveniste, Ségolène Toquet, Océane

Landon-Cardinal

\section{- To cite this version:}

Yves Allenbach, Lois Bolko, Olivier Benveniste, Ségolène Toquet, Océane Landon-Cardinal. Reply: Janus kinase $1 / 2$ inhibition with baricitinib in the treatment of juvenile dermatomyositis. Brain - A Journal of Neurology , 2019, 142 (3), pp.e9-e9. 10.1093/brain/awz006 . hal-03523485

\section{HAL Id: hal-03523485 \\ https://hal.sorbonne-universite.fr/hal-03523485}

Submitted on 12 Jan 2022

HAL is a multi-disciplinary open access archive for the deposit and dissemination of scientific research documents, whether they are published or not. The documents may come from teaching and research institutions in France or abroad, or from public or private research centers.
L'archive ouverte pluridisciplinaire HAL, est destinée au dépôt et à la diffusion de documents scientifiques de niveau recherche, publiés ou non, émanant des établissements d'enseignement et de recherche français ou étrangers, des laboratoires publics ou privés. 


\title{
Reply: Janus kinase I/2 inhibition with baricitinib in the treatment of juvenile dermatomyositis
}

\author{
Yves Allenbach,' Lois Bolko,' Ségolène Toquet, ${ }^{2}$ Océane Landon-Cardinal $^{1,3}$ and \\ Olivier Benveniste'
}

1 Sorbonne Université, INSERM UMRS_974, Center of Research in Myology, AP-HP, Department of Internal Medicine and Clinical Immunology, DHU I2B, Pitié-Salpêtrière Hospital, F-75013, Paris, France

2 Department of Internal Medicine, Clinical Immunology and Infectious Diseases, Robert Debré Hospital, University Hospital, Reims, France

3 Division of Rheumatology, Department of Medicine, Centre Hospitalier de l'Université de Montréal, Montréal, Canada

Correspondence to: Dr Yves Allenbach

Department of Internal Medicine and Clinical Immunology

DHU I2B, Pitié-Salpêtrière Hospital, 75013, Paris, France

E-mail: yves.allenbach@aphp.fr

Sir,

In their letter Papadopoulou et al. (2019) report the case of a severe juvenile dermatomyositis (JDM) case refractory to several lines of conventional immunosuppressants (methotrexate, cyclophosphamide, azathioprine, mycophenolate mofetil, tacrolimus and ciclosporin), biological agents (infliximab, rituximab and adalimumab) and intravenous immunoglobulins, who was dramatically improved (skin and muscular involvement) by a Janus Kinase 1/2 (JAK1/ 2) inhibitor (baricitinib). At last follow up, corticosteroids were tapered and the patient was in remission.

Interestingly, the patient relapsed when his medications (baricitinib and corticosteroids) were discontinued and subsequently rapidly improved after JAK inhibitor reintroduction, highlighting its efficacy.

This is the second report of a JDM case successfully treated with JAK1/2 inhibitor. Recently, Aeschlimann et al. (2018) describe a very severe refractory juvenile patient dramatically improved by ruxolitinib, another JAK1/2 inhibitor. To our knowledge there are no other published cases of JDM treated with JAK inhibitors.

These observations are in line with previous reports in adult refractory dermatomyositis patients $(n=17)$ who improved with JAK inhibitors (Allenbach et al., 2018). Recently, preliminary results of an open label pilot study evaluating tofacitinib (JAK1/2/3 inhibitor) in refractory adult dermatomyositis patients were presented (Paik et al., 2018). All patients $(n=9)$ met the primary endpoint (definition of improvement based on International Myositis Assessment Clinical Studies) and half of them demonstrated a moderate improvement (based on American Congress Rheumatology/European League Against Rheumatism criteria) (Aggarwal et al., 2017).

The rationale of JAK inhibitor use is provided by the strong interferon (IFN) pathway activation displayed in the peripheral blood, the muscular and the skin compartments (Wong et al., 2012) of patients with dermatomyositis and the demonstration in vitro of the pathogenic role of IFN on muscular and endothelial cells (Ladislau et al., 2018). Indeed, the JAK family (encompassing JAK 1, 2 and 3) plays a central role in signalling transduction for multiple cytokines as well as growth factors, and JAK1 proteins mediate intracellular signalling from IFN transmembrane receptor, leading to STAT1 phosphorylation.

Papadopoulou et al. (2019) showed that IFN stimulated gene expression significantly decreased as well as STAT1 phosphorylation in peripheral blood mononucleated cells during treatment with baricitinib. Since baricitinib is a JAK $1 / 2$ inhibitor and that JAK 1 and 2 proteins are involved in signalling of other cytokines other than IFN (e.g. IL-2, IL-4 or IL-6) one cannot exclude that the clinical improvement may also involve other pathway blockage.

The patient did not develop infectious adverse event including herpes zoster, which seems specific to JAK inhibitor therapy (Cohen et al., 2014). In addition, Papadopoulou et al. 
highlighted that the patient growth was normal during baricitinib exposure considering that JAK2 also transduces growth hormone signal. To overcome these adverse events, including JAK2 dependant haematopoietic toxicity, the development of a 'second generation' of selective blockade of JAK1 or JAK3 are ongoing, yet disappointing results concerning their toxicity profile has been reported (Gadina et al., 2016).

Another interesting finding in the patient reported by Papadopoulou et al. was the absence of progression of calcification after JAK inhibition, as it was reported in the other JDM case treated with JAK inhibitor (Aeschlimann et al., 2018). This observation suggests an efficacy of JAK inhibitor on the vasculopathy since there is an association between calcinosis and the presence of vascular injury (Valenzuela et al., 2014). Nevertheless, in both cases, JAK inhibitors failed to improve the calcinosis.

Papadopoulou et al. provide a new observation demonstrating yet again the great potential of JAK inhibitor to treat juvenile as well as adult refractory dermatomyositis patients.

\section{Data availability}

Data sharing is not applicable to this article as no new data were created or analysed in this work.

\section{Competing interests}

The authors report no competing interests.

\section{References}

Aeschlimann FA, Frémond M-L, Duffy D, Rice GI, Charuel J-L, Bondet V, et al. A child with severe juvenile dermatomyositis treated with ruxolitinib. Brain J Neurol 2018; 141: e80.

Aggarwal R, Rider LG, Ruperto N, Bayat N, Erman B, Feldman BM, et al. 2016 American College of Rheumatology/European League Against Rheumatism criteria for minimal, moderate, and major clinical response in adult dermatomyositis and polymyositis: an International Myositis Assessment and Clinical Studies Group/ Paediatric Rheumatology International Trials Organisation Collaborative Initiative. Ann Rheum Dis 2017; 76: 792-801.

Allenbach Y, Toquet S, Landon-Cardinal O, Benveniste O. Reply: a child with severe juvenile dermatomyositis treated with ruxolitinib. Brain J Neurol 2018; 141: e81.

Cohen S, Radominski SC, Gomez-Reino JJ, Wang L, Krishnaswami S, Wood SP, et al. Analysis of infections and all-cause mortality in phase II, phase III, and long-term extension studies of tofacitinib in patients with rheumatoid arthritis. Arthritis Rheumatol 2014; 66: 2924-37.

Gadina M, Schwartz DM, O'Shea JJ. Decernotinib: a next-generation Jakinib. Arthritis Rheumatol 2016; 68: 31-4.

Ladislau L, Suárez-Calvet X, Toquet S, Landon-Cardinal O, Amelin D, Depp $\mathrm{M}$, et al. JAK inhibitor improves type I interferon induced damage: proof of concept in dermatomyositis. Brain J Neurol 2018; 141: 1609-21.

Papadopoulou C, Hong Y, Omoyinmi E, Brogan PA, Eleftheriou D. Janus kinase $1 / 2$ inhibition with baricitinib in the treatment of juvenile dermatomyositis. Brain 2019. doi: 10.1093/brain/awz005.

Paik JJ, Albayda J, Tiniakou E, Koenig A, Christopher-Stine L. Study of tofacitinib in refractory dermatomyositis (STIR): an open label pilot study in refractory dermatomyositis [abstract]. Arthritis Rheumatol 2018; 70 (suppl 10). https://acrabstracts.org/abstract/s.

Valenzuela A, Chung L, Casciola-Rosen L, Fiorentino D. Identification of clinical features and autoantibodies associated with calcinosis in dermatomyositis. JAMA Dermatol 2014; 150: 724-9.

Wong D, Kea B, Pesich R, Higgs BW, Zhu W, Brown P, et al. Interferon and biologic signatures in dermatomyositis skin: specificity and heterogeneity across diseases. PloS One 2012; 7: e29161. 